\title{
Sergio Cappello, «Décalages contre-textuels: la mise en prose du Manteau mal taillé du XVI $\mathrm{X}^{\mathrm{e}}$ siècle»
}

\author{
Maria Colombo Timelli
}

\section{(2) OpenEdition}

\section{Journals}

Édition électronique

URL : http://journals.openedition.org/studifrancesi/1293

DOI : 10.4000/studifrancesi. 1293

ISSN : 2427-5856

Éditeur

Rosenberg \& Sellier

\section{Édition imprimée}

Date de publication : 1 décembre 2015

Pagination : $577-578$

ISSN : 0039-2944

\section{Référence électronique}

Maria Colombo Timelli, « Sergio Cappello, «Décalages contre-textuels: la mise en prose du Manteau mal taillé du xvIe siècle» », Studi Francesi [En ligne], 177 (LIX | III) | 2015, mis en ligne le 01 décembre 2015, consulté le 06 janvier 2021. URL : http://journals.openedition.org/studifrancesi/1293 ; DOI : https:// doi.org/10.4000/studifrancesi.1293

Ce document a été généré automatiquement le 6 janvier 2021.

\section{(c)}

Studi Francesi è distribuita con Licenza Creative Commons Attribuzione - Non commerciale - Non opere derivate 4.0 Internazionale. 


\title{
Sergio Cappello, «Décalages contre- textuels: la mise en prose du Manteau mal taillé du XVI siècle»
}

\author{
Maria Colombo Timelli
}

\section{RÉFÉRENCE}

SERGIO CAPPELLO, «Décalages contre-textuels: la mise en prose du Manteau mal taillé du $\mathrm{XVI}^{\mathrm{e}}$ siècle», in «Romanica» 16 - Études Romanes. Hommages offerts à Florica Dimitrescu et Alexandru Niculescu, Éditions de l'Université de Bucarest, 2013, pp. 135-144.

1 Le récit connu sous le titre de Mantel mautaillé est un conte en vers octosyllabiques difficile à classer, mais dont la visée parodique semble certaine: fabliau ou lai breton composé vraisemblablement entre la fin $d u$ XII $^{\mathrm{e}}$ et le début du XIII ${ }^{\mathrm{e}}$ siècle, il est centré sur l'épreuve de fidélité, proposée dans le cadre de la cour arthurienne. Sergio Cappello présente ici la version en prose transmise par le manuscrit fr. 2153 de la $\mathrm{BnF}\left(\mathrm{xvI}^{\mathrm{e}}\right.$ siècle) en s'arrêtant sur les modifications introduites par le prosateur anonyme: cellesci portent essentiellement sur l'incipit, l'explicit, l'onomastique et surtout sur une présence appuyée de Morgane; le dénouement diffère aussi du texte médiéval, le couple exemplaire formé par Caradoc et son amie quittant la cour pour vivre heureux en dehors du monde arthurien. L'existence d'une édition imprimée (Lyon, François Didier, ca 1570), dont aucun exemplaire n'est conservé, est témoignée tant par Du Verdier que, beaucoup plus tard, par le Marquis de Paulmy, qui en donna un bref résumé dans la Bibliothèque Universelle des Romans de février 1777. En tant que seiziémiste, Sergio Cappello s'interroge surtout sur le sens de ces réélaborations en prose d'un récit médiéval qui avait perdu de sa prégnance et qui n'avait plus de chances de «parler» aux lecteurs de la seconde moitié du Xvi siècle. 